\title{
Acute Iron Dextran Injection Increases Liver Weight and Reduces Glycerol Kinase Expression in Liver
}

\author{
Ramdan Panigoro, 1,2 , Fadhal M. Ahmad ${ }^{3}$, Uni Gamayani ${ }^{4}$, Neni Anggraeni, \\ Rini Widyastuti ${ }^{6,7}$, Mohammad Ghozali ${ }^{1,2}$, Mas Rizky A.A Syamsunarno ${ }^{1,2,7}$ \\ ${ }^{1}$ Department of Biomedical Sciences, Faculty of Medicine, Universitas Padjadjaran, Sumedang, \\ Indonesia, ${ }^{2}$ Study Center of Medical Genetics, Faculty of Medicine, Universitas Padjadjaran, \\ Sumedang, Indonesia, ${ }^{3}$ Undergraduate Medical Study Program, Faculty of Medicine, \\ Universitas Padjadjaran, Sumedang, Indonesia, ${ }^{4}$ Department of Neurology, Faculty \\ of Medicine, Universitas Padjadjaran, Sumedang, Indonesia, ${ }^{5}$ Medical Laboratory \\ Technologist, Bakti Asih School of Analyst, Bandung, Indonesia, ${ }^{6}$ Laboratory of \\ Animal Reproduction and Artificial Insemination, Department of Animal Production, \\ Animal Husbandry Faculty, Universitas Padjadjaran, Sumedang, Indonesia, \\ ${ }^{7}$ Central Laboratory, Universitas Padjadjaran, Sumedang, Indonesia
}

\begin{abstract}
Iron is essential and needed in a very small amount. When iron exceeds normal need, metabolic alteration occurs, causing hepatosteatosis. The mechanism of iron inducing hepatosteatosis remains unclear. Glycerol kinase, the enzyme responsible in triglyceride synthesis initiation, is assumed to have a role in the pathomechanism of hepatosteatosis. This study aimed to investigate the gene expression of glycerol kinase in an acute iron overload condition. This study was conducted in Animal Laboratory Faculty of Medicine and Central Laboratory Universitas Padjadjaran from May to June 2017. Three groups of mice were divided by the dose of iron dextran injection $(0,0.1,0.3 \mathrm{mg} /$ day $/ \mathrm{mice})$. After 19 days, mice were terminated, liver weight was measured and glycerol kinase gene expression in the liver was determined by semi-qualitative PCR. Quantification of PCR result was calculated by ImageJ software. There was a significant change in liver weight of the mice in a dose-dependent manner of iron injection. The expression of glycerol kinase tended to decrease, but statistically insignificant. Acute iron dextran injection increases liver weight and tends to reduce glycerol kinase gene expression in mice liver.
\end{abstract}

Keywords: Glycerol kinase, hepatosteatosis, iron overload

\section{Efek Zat Besi Dosis Tinggi Akut dalam Meningkatkan Berat Organ dan Menurunkan Ekspresi Gliserol Kinase Hepar}

\begin{abstract}
Abstrak
Zat besi merupakan nutrien esensial dan diperlukan dalam jumlah yang sangat kecil. Ketika kadar zat besi melebihi kadar normal dalam tubuh, terjadi perubahan metabolisme yang menyebabkan hepatosteatosis. Mekanisme zat besi dalam menyebabkan hepatosteatosis masih belum diketahui secara pasti. Gliserol kinase, enzim yang menginisiasi sintesis trigliserida, diduga berperan dalam patomekanisme hepatosteatosis. Penelitian ini bertujuan untuk meneliti ekspresi gen gliserol kinase pada hepar pada kondisi tinggi zat besi akut. Penelitian ini dilakukan di Laboratorium Hewan Fakultas Kedokteran dan Laboratorium Sentral Universitas Padjadjaran dari bulan Mei sampai dengan Juni 2017. Tiga kelompok mencit dibagi berdasarkan dosis injeksi iron dextran intraperitoneal $(0,0,1,0,3 \mathrm{mg} /$ hari/ekor). Setelah 19 hari, mencit diterminasi, berat hepar ditimbang dan ekspresi gen gliserol kinase diukur dengan metode semi-kualitatif PCR. Kuantifikasi hasil PCR dilakukan dengan menggunakan aplikasi ImageJ. Terdapat peningkatan berat hepar secara signifikan yang sejalan dengan dosis ijeksi zat besi. Ekspresi gen gliserol kinase cenderung menurun, meskipun secara statistik tidak signifikan. Keadaan tinggi kadar zat besi yang akut meningkatkan berat hepar dan cenderung menurunkan ekspresi gen gliserol kinase pada hepar mencit.
\end{abstract}

Kata kunci: Gliserol kinase, hepatosteatosis, zat besi berlebih

Correspondence: Mas Rizky A.A Syamsunarno, dr., M.Kes., PhD., Department of Biomedical Sciences, Faculty of Medicine Universitas Padjadjaran, Sumedang, West Java 45363, Indonesia, email: rizky@unpad.ac.id Received: 27 ${ }^{\text {th }}$ June 2018, Accepted: $8^{\text {th }}$ November 2018, Published: $1^{\text {st }}$ December 2018 


\section{Introduction}

Iron is essential to our body and needed in very small amount. ${ }^{1}$ Iron is not excreted actively by the body, therefore it accumulated easily in the body when dysregulation or excessive intake occurred. ${ }^{2}$ Normally, iron is regulated by hepcidin and stored in form of ferritin and hemosiderin in the spleen, small intestine, skeletal muscle, and mostly in liver. ${ }^{3}$

Chronic anemia experienced by thalassemia patient needs a repetitive blood transfusion to replenish red blood cells. However, this definite therapy can lead to iron overload. Another condition, such as gene mutation as seen in hemochromatosis can lead to iron overload condition. ${ }^{2}$ Iron overload is defined as an excessive accumulation of iron in the body. ${ }^{4}$ This condition can produce severe complication such as liver damage, cardiomyopathy, and endocrine morbidities, ${ }^{5}$ and excessive iron inside the body will form a reactive oxygen species (ROS) and a lipid peroxidation via Fenton and Haber-Weiss reaction. ${ }^{6-8}$ ROS and lipid peroxidation formed were known to cause mitochondrial dysfunction. ${ }^{9}$ This unfavorable condition decreased the number of ATP produced by the cell. ${ }^{10}$

The liver is the primary organ for a metabolic process which also has a pivotal role as the main site of iron storage and distribution from hepatocyte to circulation, particularly when there is a metabolic need. ${ }^{6-9}$ Cellularly, iron overload is indicated by increased ferritin and hemosiderin level which end up with fibrosis. The adaptation of this change leads to an increase in the amount of the liver or even may cause carcinoma..$^{7,6,11,12}$ Sengsuk et al. suggested that iron overload is related with the alteration of lipid metabolism proved by the correlation between increased ferritin level and serum triglyceride forming an intra-hepatic triglyceride called hepatosteatosis. ${ }^{8,13-15}$ It has been proven that chronic hepatosteatosis may mediate inflammation and fibrogenesis. ${ }^{16}$
Recent studies have been focused on revealing the mechanism of the pathogenic pathway leading to an increase of intrahepatic triglyceride. The increase of lipid dietary uptake and increase of lipolysis induce-increase of glycerol serum level which leads to an increase of triglyceride synthesis in the liver, are a wellknown cause of an increase of intrahepatic triglyceride. ${ }^{17,18}$ Sn-glycerol-3-phosphate is one of three common pathways in triglyceride synthesis; the rests are dihydroxyacetone phosphate and monoacylglycerol pathway. Sn- glycerol-3-phosphate mainly occurs in liver, and glycerol kinase is an enzyme that catalyzes a reaction between adenosine triphosphate (ATP) and glycerol to yield sn-glycerol-3phosphate and adenosine diphosphat (ADP). ${ }^{19,20}$ Other pathways are mostly occurred in adipocyte and in enterocyte. ${ }^{19}$

The purpose of this study was to investigate the expression of the glycerol kinase gene under an acute iron overload condition. We hypothesized that the expression of the glycerol kinase gene was changed in the iron overload condition and could lead to intrahepatic triglyceride accumulation. We used DDY mice strain in our animal experimental study to create a model of iron overload patient.

\section{Methods}

Acute iron overload mice model

This research was approved by the Health Research Ethics Committee Faculty of Medicine Universitas Padjadjaran (No. 43/UN6.C1.3.2/ $\mathrm{KEPK} / \mathrm{PN} / 2017$. Mice strain DDY aged 10 to 12 weeks old were purchased from Biofarma and housed in Animal Laboratory of Faculty of Medicine, Universitas Padjadjaran with a condition of $12 \mathrm{~h} / 12$ light and dark, adequate air circulation, food, and water supply. Mice were acclimatized in the laboratory for 7 days before the intervention.

This study was conducted as previously described. ${ }^{21}$. Iron solutions were made by diluting 
iron dextran (Hemadex, Sanbe, Indonesia) in $200 \mathrm{ml}$ of $\mathrm{NaCl} 0.9 \%$. Mice were divided into 3 groups: control, group 1 and group 2 with dose $0,0.1$ and $0.3 \mathrm{mg}$ iron dextran, respectively. A total of $200 \mathrm{ml}$ saline and iron solution were injected intraperitoneally for 19 days. After 19 days of treatment, mice were sacrificed by cervical dislocation, the liver was harvested and liver weight was measured. The liver was snapped frozen in liquid nitrogen and stored in $-80{ }^{\circ} \mathrm{C}$.

RNA isolation, cDNA synthesis and polymerase chain reaction (PCR)

Total RNA from liver was collected by using TRIzol (Invitrogen) according to the manufacturer standard protocol. Briefly, 50 mg of liver was homogenized with $500 \mu \mathrm{L}$ TRIzol reagent and RNA-contained solution was collected after added $100 \mu \mathrm{L}$ chloroform and centrifuged $13.000 \mathrm{x}$ rpm for 15 minutes. RNA-contained solution was further precipitated with isopropanol, washed with $70 \%$ ethanol and homogenized with RNase free water.

cDNA synthesis was performed by using ReverTra Ace ${ }^{\circledR}$ qPCR RT Master Mix (Toyobo), followed by semi-qualitative PCR by using rTaq DNA Polymerase (Toyobo) kit according to the manufacturer protocol.
Target gene expression level was normalized by using GAPDH mRNA levels. The PCR product was applied to gel electrophoresis and the band was quantified using Image J 1.51 application. ${ }^{22}$ Primer list are described as follows: Glycerol Kinase-forward: gctgtaa tccgctggctaag; Glycerol Kinase-reverse: atg g catccaaaatctctcg; GAPDH-forward: tccaccac cctgttgctgta; GAPDH-reverse: accacagtccatg ccatcac.

\section{Statistical analysis}

GraphPad Prism 7 (La Jolla, USA) was used in our statistical analysis. All results were analyzed by using D'Agustino Pearson and Kolmogorov-Smirnov for normal distribution. One-way ANOVA was chosen to evaluate the differences between groups, followed by Bonferroni Post Hoc Test. A p-value $<0.05$ was considered as statistically significant.

\section{Results}

Increase of liver weight after iron dextran injection

Liver weights of all samples were measured. After 19 days of saline or iron dextran injection, the liver weight in control group was $1.40 \pm$ 0.15 gram, while the liver weight in group 1

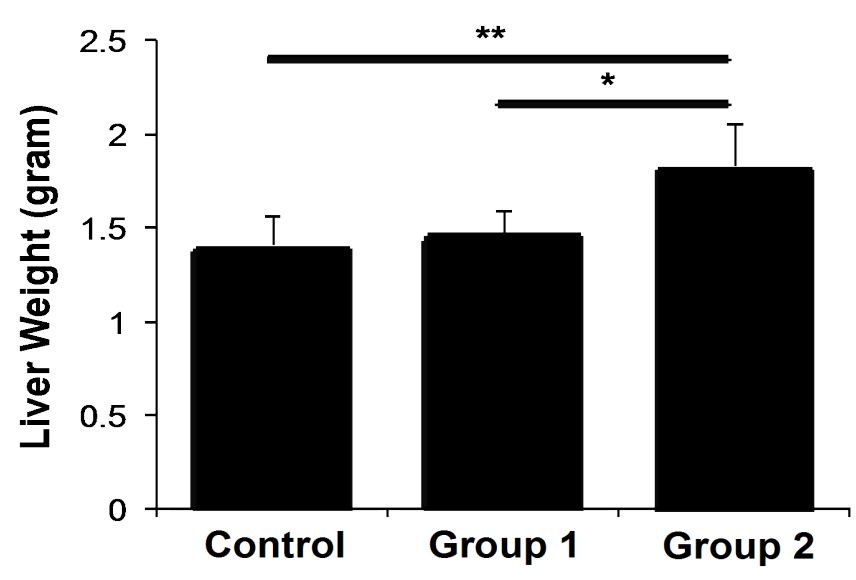

Figure 1 The Liver Weight after Saline and Iron Dextran Injection

The liver weight was highest in mice injected with $0.3 \mathrm{mg}$ iron dextran (group 2). ( $\mathrm{n}=6-7$ mice/group; * $\mathrm{p}=0.006$; $* * \mathrm{p}=0.001)$ 


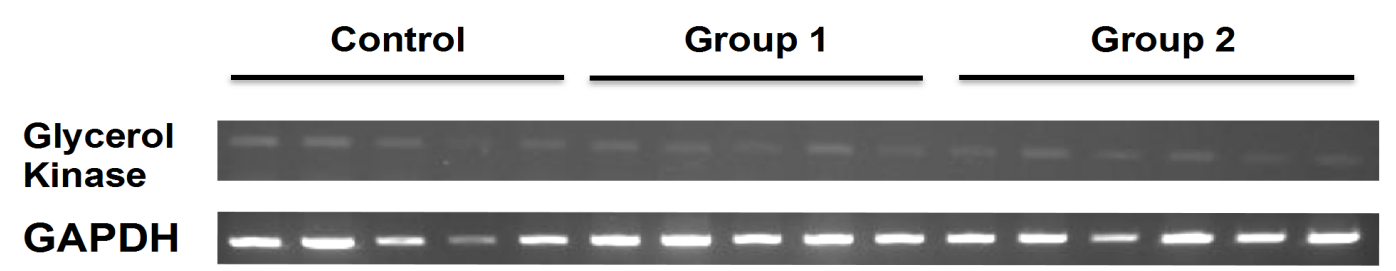

Figure 2 The Gene Expression of Glycerol Kinase and GAPDH in the Liver after Saline and Iron Dextran Injection

and 2 was $1.47 \pm 0.11$ gram and $1.82 \pm 0.22$ gram, respectively (Figure 1). Liver weight was increased proportionally allow to iron dextran dose. Statistical analysis showed that the liver weight in group 2 was increased highly significantly compared to the control group $(\mathrm{p}=0.01)$ and group $2(\mathrm{p}=0.06)$. There were no statistically different in liver weight control and group 1.

A tendency of glycerol kinase gene expression to decrease after iron dextran injection

The gene expression of glycerol kinase tended to decrease after iron dextran injection (Figure 2). Unfortunately, quantification of PCR band showed that there was no difference in gene expression level (control $=1.00 \pm 0.42$; group $1=$ $0.76 \pm 0.12$; group $2=0.60 \pm 0.28$ ) (Figure 3 ).

\section{Discussion}

Hepatosteatosis pathogenesis related to iron overload experienced in major thalassemia patients prevalence remains unclear. ${ }^{23}$ Studies have been conducted to know the mechanism of hepatosteatosis and the main etiology of the disease. There are pieces of evidence that iron overload is correlated with hepatosteatosis. Insulin resistance due to damage of pancreas and or insulin resistance in target organs has been associated with hepatosteatosis. ${ }^{24}$ Insulin resistance in adipose tissue promotes lipid breakdown and releases fatty acid into the circulation, causing accumulation of fatty acid in the liver. ${ }^{25}$ However, it is unknown whether there are correlations of iron deposit with de novo lipid synthesis in the liver., ${ }^{6,11,12}$

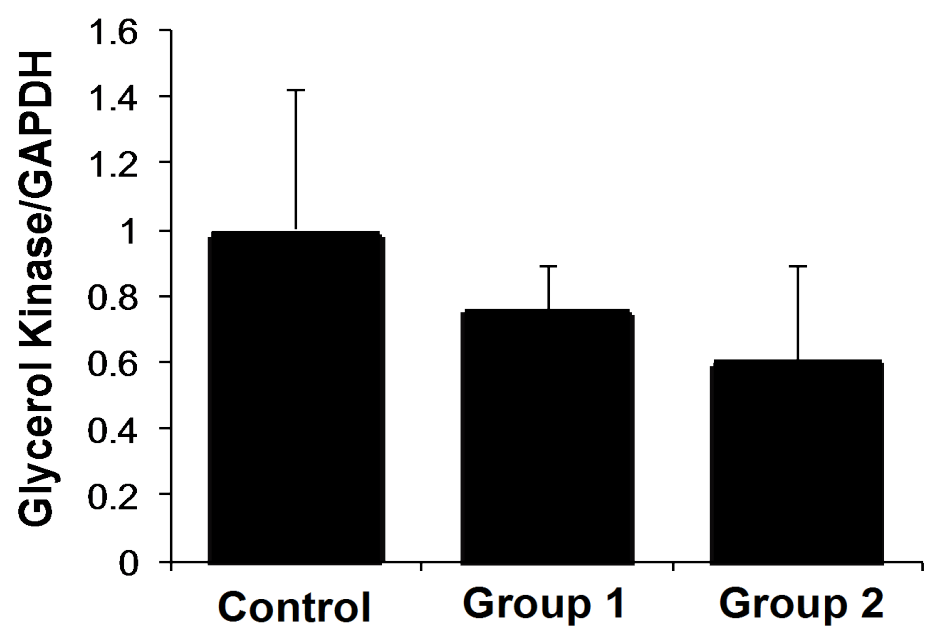

Figure 3 Glycerol Kinase Gene Expression after Quantified with ImageJ Software and Normalized with GAPDH

Glycerol kinase expression tended to decrease after iron dextran injection ( $\mathrm{n}=5-6$ mice/group) 
In the present study, an increase of liver weight indicated there was enlargement of the liver. The hepatocyte is the main site of iron and triglyceride deposit when the amount of these become excessive. ${ }^{6,7}$ Liver maintains iron balance in circulation by producing the protein mantaining iron balance in systemic. Iron was stored in liver and it is mobilized into circulation to maintain the iron level in systemic. In excessive condition, iron stored within the liver on ferritin and hemosiderin form. High concentration of iron in the liver induce an increase in liver weight. Non-binding iron in the liver induce production of reactive oxygen species and lead to inflammation. This condition can induce liver enlargement due to hepatocyte swelling. However, injection of iron dextran $0.1 \mathrm{mg} /$ day resulted in no increase of liver weight, suggested a certain cut off dose and or duration of iron dextran injection are necessary to increase liver weight.

The accumulation of triglyceride in the liver can increase liver weight. ${ }^{23,26}$ The high iron level in the human body has been showed to correlate with triglyceride accumulation in liver such as in alcoholic liver diseases or non-alcoholic fatty liver disease. ${ }^{27}$ In chronic of blood transfusion as seen in thalassemia patient with prolonged blood transfusion, the serum level of ferritin is correlated with the high level of a marker of hepatic dysfunction such as alanine aminotransferase (ALT) and aspartate aminotransferase (ASP). ${ }^{27}$ Furthermore, the serum triglyceride is also increased in thalassemia patient with blood transfusion. ${ }^{28}$ However, it is not clear how the mechanism of triglyceride accumulation in the liver. Our study is focused to investigate the impact of iron overload only in the early phase. Further experiments including the measurement of hepatic tissue iron level, triglyceride content, and proteins involved in fibrogenesis are necessary to confirm what might cause the increase in liver weight.

Triglyceride is synthesized in a three-way; dihydroxyacetone phosphate, monoacylglycerol, and sn-glycerol-3 phosphate pathway. The first mostly occurs in adipose tissue, the second is in enterocyte, and the last is in the hepatocyte. Even though, all those three pathways can occur in any site. ${ }^{19} \mathrm{We}$ presumed that there would be an increase of gene expression of glycerol kinase as the main marker in sn-3glycerol phosphate pathway. However, our finding showed that expression of glycerol kinase tends to decrease after 19 days of iron dextran injection. From this result, it might be assumed that the triglyceride synthesis is not triggered in the early phase of an iron overload condition, particularly during excess iron condition is not using the sn-3-glycerol phosphate pathway. Other possibilities are the dosage and or duration of treatment to the mice are insufficient to cause manifestation that we expected.

\section{Conclusion}

Acute iron dextran injection increases liver weight and tends to reduce glycerol kinase expression in mice liver.

\section{Funding}

This study was funded by Academic Leadership Grant Universitas Padjadjaran 2017.

\section{Conflict of Interest}

The authors declare no conflict of interest.

\section{References}

1. Abbaspour N, Hurrell R, Kelishadi R. Review on iron and its importance for human health. J Res Med Sci. 2014;19(2): 164-74.

2. Kohgo Y, Ikuta ÆK, Ohtake ÆT. Body iron metabolism and pathophysiology of iron overload. 2008;88(1):7-15. doi: 10.1 
007/s12185-008-0120-5]

3. Oliveira F, Rocha S, Fernandes R. Iron metabolism: From health to disease. J Clin Lab Anal. 2014;28(3):210-8. doi: 10.100 2/jcla.21668

4. Meroño T, Rosso LG, Sorroche P, Boero L, Arbelbide J, Brites F. High risk of cardiovascular disease in iron overload patients. Eur J Clin Invest. 2011;41(5): 479-86. doi: 10.1111/j.1365-2362.2010.0 2429.x.

5. Berdoukas V, Farmaki K, Carson S, Wood J, Coates T. Treating thalassemia major-related iron overload: The role of deferiprone. J Blood Med. 2012;3:119-29. doi: 10.2147/JBM.S27400

6. Anderson ER, Shah YM. Iron homeostasis in the liver. Compr Physiol. 2013;3(1):315 -30. doi: 10.1002/cphy.c120016.

7. Saito H. Metabolism of iron stores. Nagoya J Med Sci. 2014;76(3-4):235-54.

8. Sengsuk C, Tangvarasittichai $\mathrm{O}$, Chantanaskulwong $\mathrm{P}$, Pimanprom A, Wantaneeyawong S, Choowet A, et al. Association of iron overload with oxidative stress, hepatic damage and dyslipidemia in transfusion-dependent $\beta$-thalassemia/ $\mathrm{HbE}$ patients. Indian J Clin Biochem. 2014; 29(3):298-305. doi: 10.1007/s12291-013 $-0376-2$

9. Gao X, Campian JL, Qian M, Sun XF, Eaton JW. Mitochondrial DNA damage in iron overload. J Biol Chem. 2009;284 (8):4767-75. doi: 10.1074/jbc.M8062352 00

10. Plowman S, Smith DL. Energy production. Exerc Physiol Heal Fit Perform. 2011;18: 26-54.

11. Ahmed U, Latham PS, Oates PS. Interactions between hepatic iron and lipid metabolism with possible relevance to steatohepatitis. World J Gastroenterol. 2012;18(34):4651-8. doi: 10.3748/wjg.v 18.i34.4651

12. Parisi GF, Di Dio G, Franzonello C,
Gennaro A, Rotolo N, Lionetti E, et al. Liver disease in cystic fibrosis: An update. Hepat Mon. 2013;13(8):e11215. doi: 10.5 812/hepatmon.11215]

13. Udipi S, Ghugre P, Gokhale C. Iron, oxidative stress and health. In: Oxidative stress-molecular mechanisms and biological effects. InTech. 2012;73-108. doi: 10.577 2/34975

14. Gena P, Mastrodonato M, Portincasa P, Fanelli E, Mentino D, Rodríguez A, et al. Liver glycerol permeability and aquaporin-9 are dysregulated in a murine model of non-alcoholic fatty liver disease. PLoS One. 2013;8(10):e78139. doi: 10.1371/journal. pone.0078139

15. Browning JD, Szczepaniak LS, Dobbins R, Nuremberg P, Horton JD, Cohen JC, et al. Prevalence of hepatic steatosis in an urban population in the United States: Impact of ethnicity. Hepatology. 2004;40 (6):1387-95. doi: 10.1002/hep.20466

16. Leandro G, Mangia A, Hui J, Fabris P, Rubbia-Brandt L, Colloredo G, et al. Relationship between steatosis, inflammation, and fibrosis in chronic hepatitis C: A meta-analysis of individual patient data. Gastroenterology. 2006;130(6):1636-42. doi: 10.1053/j.gastro.2006.03.014

17. Koopman KE, Caan MWA, Nederveen AJ, Pels A, Ackermans MT, Fliers E, et al. Hypercaloric diets with increased meal frequency, but not meal size, increase intrahepatic triglycerides: A randomized controlled trial. Hepatology. 2014;60(2): 545-53. doi: 10.1002/hep.27149

18. Ress C, Kaser S. Mechanisms of intrahepatic triglyceride accumulation. World J Gastroenterol. 2016;22(4):1664-73. doi: 10.3748/wjg.v22.i4.1664.

19. Lipid Home. Tracylglycerols: Biosynthesis and metabolism [Accessed on: $23^{\text {rd }}$ August 2017]. Available at: http://www.lipidhom e.co.uk/lipids/simple/tag2/index.htm

20. UniProt. Glycerol kinase protein [Accessed 
on: $23^{\text {rd }}$ August 2017]. Available at: http:// www.uniprot.org/uniprot/P32189

21. Sari SP, Syamsunarno MRAA, Susanah S, Atik N, Ghozali M, Safitri R, et al. The effect of excess iron on the impairment of glucose metabolism in mice. J Biomed Clin Sci. 2017;2(2):8-10.

22. Schneider CA, Rasband WS, Eliceiri KW. NIH Image to ImageJ: 25 years of image analysis historical commentary. Nat Methods. 2012;9(7):671-5.

23. Nelson JE, Wilson L, Brunt EM, Yeh MM, David E, Unalp-arida A, et al. Relationship between the pattern of hepatic iron deposition and histological severity in nonalcoholic fatty liver disease. Hepatology. 2011;53(2):448-57. doi: 10.1002/hep.24 038.

24. Nelson JE, Klintworth H, Kowdley KV. Iron metabolism in nonalcoholic fatty liver disease. Curr Gastroenterol Rep. 2012;14 (1):8-16. doi: 10.1007/s11894-011-02344.

25. Donnelly KL, Smith CI, Schwarzenberg SJ, Jessurun J, Boldt MD, Parks EJ.
Sources of fatty acids stored in liver and secreted via lipoproteins in patients with nonalcoholic fatty liver disease. J Clin Invest. 2005;115(5):1343-51. doi: 10.117 2/JCI23621

26. Syamsunarno MRAA, Iso T, Hanaoka $H$, Yamaguchi A, Obokata M, Koitabashi N, et al. A critical role of fatty acid binding protein 4 and 5 (FABP4/5) in the systemic response to fasting. PLoS One. 2013;8 (11):e79386. doi: 10.1371/journal.pone.0 079386.

27. Milic S, Mikolasevic I, Orlic L, Devcic E, Starcevic-Cizmarevic N, Stimac D, et al. The role of iron and iron overload in chronic liver disease. Med Sci Monit. 2016;22:2144-51. doi: 10.12659/MSM.8 96494

28. Shams S, Ashtiani MTH, Monajemzadeh M, Koochakzadeh L, Irani H, Jafari F, et al. Evaluation of serum insulin, glucose, lipid profile, and liver function in $\beta$-thalassemia major patients and their correlation with iron overload. Lab Med. 2010;41(8):4869. doi: 10.1309/LMS0EOOUZSII2BNE

(C) 2018 Panigoro et al. The full terms of this license incorporate the Creative Common Attribution-Non Commercial License (https:// creativecommons.org/licenses/by-nc/4.0/). By accessing the work you hereby accept the terms. Non-commercial use of the work are permitted without any further permission, provided the work is properly attributed. 